\title{
How the Modern Economy and Regulation Grew up Together
}

\author{
John Steele Gordon
}

Published online: 28 March 2012

(C) Springer Science+Business Media, LLC 2012

In the middle third of the 18th century, the factory system and mechanization began to transform the economy of the Midlands of England. Accelerated by James Watt's rotary steam engine, introduced in 1784 , the new economy began to spread outwards, first to other areas of England and Scotland, then to northwest Europe, then to the new United States. Economic growth, which had seldom exceeded $1 \%$ annually in the old economy, now often reached $4 \%$ in the new.

Vast new fortunes based not on land but on manufacturing began to pile up and be reinvested in still more enterprises. In 1826 a young British novelist named Benjamin Disraeli introduced the word millionaire into English to describe the possessors of these middle-class fortunes. With their new economic power, they began demanding more political and social power. Britain and the United States accommodated these demands peacefully, many other nations did not. The Victorians thought of their time as "an age of chaos, ... . [a] heaving, tumbling age."1

In 1848, as revolution swept Europe, the new economic system acquired a name, the Industrial Revolution. But as that system gathered strength and enterprises of once unimaginable size and power began to evolve, new rules were needed to defend both the new system from self-destructing and society as a whole from the development of an economic plutocracy. As James Gordon Bennett, the founding father of modern journalism, explained in 1868, "Men no longer attempt to rule by the sword, but they find in money a weapon as sharp and more effective; and having lost none

${ }^{1}$ New York Herald, 1850.

J. S. Gordon $(\bowtie)$

PO Box 359, North Salem, NY 10560, USA

e-mail: jsg@johnsteelegordon.com of the old lust for power, they seek to establish over their fellows the despotism of dollars." 2

But because the Industrial Revolution-thanks to ever growing wealth and unceasing technological development -was an ongoing process, the development of the rules needed to protect the system and society has been an ongoing process as well.

In that sense, it is not unlike the development of the game of American football in the latter half of the 19th century. In earlier times, each college had had its own version of football. Some were rugby like and others more like soccer. In many colleges and eastern prep schools, games were played that were little more than two mobs of students each riotously trying to get the ball over the goal line of the other by any means necessary. Injuries and even deaths were not uncommon in these melees and many colleges banned such games in the 1860's.

But as colleges with different football rules started to play each other, the game of American football, with its own set of rules, began to evolve, a unique blend of rugby and soccer. The development of manufactured balls that were far more uniform than the old hand-made ones (thanks to the Industrial Revolution), allowed more precise rules to be applied.

As the game's evolution progressed, coaches would often come up with new ideas. Some of these were terrible, such as the flying wedge of the early 1880 's, where the line would link arms and form a wedge protecting the ball carrier as he advanced towards the other team's goal line. It turned out that there was no defense against the flying wedge, and injuries caused by it were far too common. The tactic was banned after only 2 years.

\footnotetext{
${ }^{2}$ New York Herald, March 19, 1868.
} 
Other ideas were brilliant, such as the forward pass that first appeared in the early 1900's. Once the rules for that tactic were formalized (no passing beyond the line of scrimmage, for instance, and certain players being ineligible to receive), it transformed the game into the one we are familiar with today. The rules of the game continue to evolve, however, if at a far slower pace. The two-point conversion was first adopted in college football in 1958 and came to the NFL only in 1994.

Modern capitalism and "the rules of the game" have evolved together in the same way and continue to do so, with such recent major rules changes as Sarbanes-Oxley and Dodd-Frank.

But it has not been just government that has developed the rules. Far from it. Many of the new entrepreneurs (a word introduced into English only in 1852) were quite as concerned with developing an economic and legal system that worked in the long term as they were with creating wealth for themselves. It was they, not government, who instituted many of the reforms and regulations that evolved along side modern industrial capitalism. The image of the greedy, indeed rapacious capitalist class being held at bay only by a vigilant government and society is a myth of the left. Often it has been government and the law that have needed reformation.

Sometimes the players of the game, recognizing their own self-interest in the game's survival, developed and enforced rules to ensure "fair play." Sometimes it was a new force in the political and economic landscape, such as modern journalism with its immense power to shape public opinion, that changed the game and enforced new rules on both capitalists and politicians alike. And often the rules that were developed in one period have themselves needed reform when the game later changed.

This is a topic worthy of a considerable book and so its history can be no more than roughly sketched here. But it is a history that provides a unique window into the development of the industrial age now ending and perhaps provides insights into what will be needed to shape the new economy now aborning, as the microprocessor transforms the world into the digital age.

$* * *$

At the beginning of the industrial era, the problem was not insufficient regulation, but far too much of it. The mercantilist theory that dominated economic thinking until Adam Smith's The Wealth of Nations was published in 1776, greatly restricted free trade. (Indeed, British restrictions on American trade were a major cause of the American Revolution). Government-granted monopolies on various commodities were common in Europe, and Britain had established such overseas trading monopolies as the British East India Company, which then ruled India, beginning in the 16th century.
Most enterprises at this time were very small by modern standards and entirely family owned and capitalized. But as industries grew, the need for capital increasingly outgrew family resources. Partnerships were one means around this. But partners were individually liable for all the debts of the partnership, making the position of limited partner, who invested but had no management responsibilities, a hazardous one. And partnerships automatically terminated with the death of any partner.

The ultimate solution to the problem was one of the great, under-sung inventions of the Renaissance, the corporation. A corporation is a legal "person" of often unlimited life span, able to contract its own debts and make its own contracts. If a corporation went broke, its investors were liable only up to the extent of their investment. This made investments in such enterprises far more enticing (and spread some of the risk to the corporation's creditors). Very risky but potentially very profitable ventures, such as long voyages to the Spice Islands, became far more economically rational. Many of the colonies in North America, including Virginia, Plymouth, New Amsterdam, and Massachusetts Bay, were founded not by governments but by joint-stock companies. None of them, except New Amsterdam, made a profit.

But in Britain, the power of incorporation lay entirely with the crown, and political influence was needed for any charter to do business as a corporation. By the end of the colonial era, only seven corporations had been created in the American colonies by the British crown. After the revolution, the successors to the British crown, the various state legislatures, also tried to husband the power.

But as the Industrial Revolution began in this country, the demand for corporate status increased. In just the last 4 years of the 18th century, 335 businesses were incorporated in the new United States. Between 1800 and 1860, just the state of Pennsylvania incorporated 2000 businesses. State legislatures simply could no longer handle the granting of separate charters for each corporation, as each required a separate legislative act.

In 1811 New York State passed the country's first general incorporation law, allowing people to form corporations just by following a set of procedures. In the first law, only certain businesses could incorporate this way, including those making linen goods and, for some reason, anchors. But soon most businesses, including, crucially, transportation and banking services could incorporate as well.

$* * *$

Of all the new enterprises of the first half of the 19th century, none was more capital intensive than the railroads. Laying the tracks alone could cost $\$ 30,000$ a mile at a time when $\$ 1000$ was a middle-class income. Rolling stock, yards, and stations cost much more in addition. 
Early railroads were usually very local affairs, connecting towns to the existing transportation grid of rivers and canals. These were usually financed by people along the route who would benefit directly by the improved transportation. But it wasn't long before these local roads began to be stitched together into longer trunk lines. The original New York Central, which ran between Albany and Buffalo, was the result of combining no fewer than nine local roads in 1853 .

Roads of this size needed far more than just local finance and that meant going to Wall Street. Wall Street had been the dominant American securities market since the 1830's, but the telegraph quickly transformed it into the only important one as people in distant cities could use the telegraph to trade in Wall Street, where the best prices were likely to be found. By 1860 the list of traded stocks on the New York Stock and Exchange Board (as the New York Stock Exchange was called until 1863) was dominated by railroad stocks.

But while Wall Street was the only important American securities market by 1860 , it still wasn't a very large one by European standards, nor was it a well-regulated one. Indeed, it was hardly regulated at all. In the small world of pre-Civil War Wall Street, it was mostly peer pressure that kept the shenanigans under control, just as it does in a back-yard touch football game.

But with the Civil War, Wall Street exploded in size and by 1865 was the second largest securities market on earth, after London, and both New York State and New York City governments were sunk deep in corruption. "In New York," the English Fraser's Magazine wrote with some wonderment in 1869, "there is a custom among litigants as peculiar to that city, it is to be hoped, as it is supreme within it, of retaining a judge as well as a lawyer."3

The main problem was that there was no regulatory body to oversee trading. Stocks were traded on the NYSE, but also on other exchanges that had opened up during the war as well as quite literally on the Street. (Known as the Curb Exchange, it wouldn't be formally organized, or even move inside, until the 1920's.) Late night trading took place at an informal exchange in the Fifth Avenue Hotel uptown on Madison Square.

For a few years Wall Street saw capitalism red in tooth and claw.

When Commodore Cornelius Vanderbilt, for instance, sought to buy control of the Erie Railway by purchasing a majority of the common stock on the open market, several directors of the railroad just kept printing new shares for him to buy and converting the proceeds into cash, draining New York of much of its ready money supply. When Vanderbilt found out what was happening, he had his judge (Justice George G. Barnard, later impeached and removed from

\footnotetext{
${ }^{3}$ Fraser's Magazine, May, 1869.
}

office) issue arrest warrants, and the directors fled to New Jersey in a row boat with $\$ 7$ million of the Commodore's money in a carpet bag.

Both sides then went to Albany to bribe the legislature into legalizing their actions. The utterly corrupt legislature that year had actually effectively legalized bribery by requiring that a conviction on that charge required evidence beyond the testimony of the other party to the bribe. In that pre-electronic age, that meant that as long as the official took the bribe in private and in cash, no conviction would be possible. As a contemporary described it, the legislators, "flocked to Albany like beeves to a cattle mart. All were for sale, and each brought a price proportioned by his weight."

This made very entertaining reading in the newspapers, which devoted more space to the so-called "Erie Wars" than they did to the simultaneous impeachment of President Andrew Johnson. But it was no way to run a capital market. Free markets are not inherently stable and the temptation to cheat is always inversely proportional to the chances of being caught and punished. The more cheating there is, the more unstable the market.

Speculators need just one big killing and therefore their stake in market stability is minimal. Brokers, however, who make their money one small commission at a time, have a great interest in market stability. In 1868, the brokers who were members of the various exchanges feared that the outof-control speculators might drive the securities business to somewhere better regulated. In 1869, when the New York Stock Exchange merged with its larger but less prestigious rival, the Open Board of Brokers, a Wall Street institution large enough and powerful enough to make and enforce rules quickly developed.

The new exchange promptly adopted new rules, such as requiring an open registry of securities, so that investors could know what securities were out there; a thirty-day public notice of new issues; and a prohibition on members of the exchange against trading listed securities on other exchanges or on the Curb.

For the first time there was a cop on the beat on Wall Street and the Street's wild-west days were over, thanks to the brokers. Government would not become deeply involved in regulating Wall Street until the 1930's, by which time it was, by orders of magnitude, the most important financial center in the world.

$* * *$

The newspapers had been an important part of the Erie Wars, and it was the newspapers that brought the corruption that so marked the New York State and City governments at that time to an end.

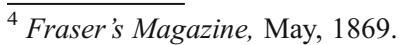


Until the development of steam presses, newspapers could print only a very limited number of copies and were thus expensive. They were also either confined to a single industry, such as shipping news, or were political in nature, in effect an editorial page wrapped in a little tendentious news.

James Gordon Bennett and the New York Herald changed that, beginning in 1835 . With the new presses able to turn out vast numbers of copies in a night at a low price per copy, Bennett aimed his new newspaper at the rising middle class, giving them news on a wide variety of topics while being politically independent. He gave them business news, stock reports, the weather, sports news, gossip and crime stories. He was the first to hire foreign correspondents and to cover Washington news with his own reporters. He even coined the word leak in the journalistic sense of the term.

Bennett's business model, which made the Herald the largest and most successful newspaper in America, was quickly copied both here and abroad. It revolutionized the news business, creating a mass audience for the first time and creating a new major force in politics, public opinion. It therefore quickly had political consequences as well. William Howard Russell's reports on the incompetence of the British war effort in the Crimea to the Times of London brought down the government of Lord Liverpool. It was the first time a government fell for reasons other than an election or political infighting.

When the New York Times began publishing the documents leaked to it by a disgruntled city employee regarding the fantastic corruption in the building of the Tweed Courthouse in New York City, the so-called Tweed Ring quickly collapsed and Boss William Tweed ended up in jail.

The standards of political behavior began to rise quickly and laws against what had once been commonplace and accepted were passed. In the 1830's Senator Daniel Webster had sent a private law client a bill for $\$ 500$ for services rendered. The particular service rendered had been to insert an amendment in a bill working its way through the Senate the effect of which was to transfer his client's case from the Alabama courts, where he had no chance of winning, to federal court, where he did. That was perfectly normal in the 1830's. A generation later it would have been considered office-selling, thanks to the new media.

$* * *$

The corporations of unprecedented size that evolved in the 19th century soon presented another problem that required regulation. Modern, double-entry bookkeeping had developed in the Renaissance, like the corporation itself, and had equal historical consequence. Large enterprises simply cannot be managed without modern accounting methods, which continue to evolve. The now-vital concept of cash flow only developed in the mid-20th century, for instance.

Until the Industrial Revolution, the people who kept the books were the same people who owned the company. They had no incentive, indeed every disincentive, to keep dishonest ones.

But once railroads and an increasing number of industrial corporations had a large number of stockholders who took no part in management, the interests of stockholders and management began to diverge. The stockholders wanted honest, complete books that would provide information that could be compared with other companies in the same industry. Management wanted books that made their stewardship look as good as possible.

Much of bookkeeping is arbitrary, and management would always choose whichever method made the bottom line look best, even if they did not lurch over into fraud. And in the middle of the 19th century there were few rules to constrain management or force them to act as the fiduciaries for the stockholders that they were.

When the Union Pacific was chartered by the federal government to help build the transcontinental railroad, for instance, the management promptly established a construction company owned by themselves. They gave it a fancy French name, Crédit Mobilier, and hired it to build the railroad, hugely overpaying their own company-and thus themselves - in the process. To make sure that Congress did not object, many influential members were well bribed with Crédit Mobilier stock.

While many members of Congress lost their seats when the scandal broke, the members of Union Pacific management went unpunished as they had committed no crime. (Today, of course, they would have been guilty of dozens.)

Many publicly traded companies issued no financial reports at all. When the New York Stock Exchange asked for information from the Delaware, Lackawanna, and Western Railroad, it was curtly informed that the "Railroad makes no report," and "publishes no statements." Even when railroads did release reports, they were often less than informative. Horace Greeley sniffed in the New York Tribune in 1870, that if the Erie Railway's annual report was accurate, then, "Alaska has a tropical climate and strawberries in their season." 6

The weekly Commercial and Financial Chronicle, the Barron's of its day, had the solution:

The one condition of success in such intrigues is secrecy. Secure to the public at large the opportunity of knowing all that a director can know of the value and prospects of his own stock, and the occupation of

\footnotetext{
${ }^{5}$ Quoted in Previts, History of Accounting, p. 81.

${ }^{6}$ New York Tribune, January 21, 1870.
} 
the "speculative director" is gone. . . . The full balance sheet . . . showing the sources and amounts of its revenues, the disposition made of every dollar, the earnings of its property, the expenses of working, of supplies, of new construction, and of repairs, the amount and form of its debt, and the disposition made of all its funds, ought to be made up and published every quarter. ${ }^{7}$

It was Wall Street's big banks and the New York Stock Exchange that imposed this essential discipline on companies beginning in the early 1880 's. They forced companies to accept the new rules by refusing to underwrite and list their securities until they agreed to issue such reports. They also imposed two other reforms to ensure honest books: what are today called Generally Accepted Accounting Principles, to ensure that company results could be easily compared with one another, and independent accountants to certify the books.

In 1884 there were only 81 self-employed accountants listed in the city directories of New York, Philadelphia, and Chicago. Five years later, there were 322. In 1896 New York State passed legislation establishing the legal basis for a new profession, certified public accountants. The statute was quickly and widely copied by other states. By World War I, the system of quarterly reports, GAAP, and independent accountants, was universal throughout American capitalism. Indeed, the only major parts of the American economy that are still not subject to such discipline are the state and federal governments. That is no small part of the reason for the current fiscal crisis in government.

$$
* * *
$$

While the constitution gives the federal government the power to regulate interstate commerce, the government did not use the power in the early years of the country. The most important assertion of federal power in this area came from the Supreme Court in 1824 with its great decision Gibbon v. Ogden. It defined federal power over commerce very broadly and forbade states from granting monopolies to local concerns. It thus assured that the United States would be the world's largest common market, just as railroads were about to come along and make national markets possible.

It was the railroads that, when Congress dithered, on their own established the system of standard time zones, giving the country a uniform way to tell time, instead of an infinity of local times. The reform caused a brief uproar at the time, but within a few years most people could not conceive of a world without standard time.

But by the end of the 19th century, railroads had become so powerful that they often abused that power. Competition on the trunk lines, such as those running between New York

\footnotetext{
${ }^{7}$ Commercial and Financial Chronicle, May $14^{\text {th }}, 1870$.
}

and Chicago, was fierce, often driving freight and passenger charges below break even. Railroads tried to deal with that by forming cartels and divvying up traffic among the cartel members. But these cartels always broke down as members cheated in order to gain market share and a new rate war would quickly break out.

While the trunk lines were fiercely competitive, the railroads often had monopolies of transportation on their branch lines, and they exploited it to the hilt to make up for losses on the trunk lines. Not surprisingly, this produced deep resentment on the part of the farmers and manufacturers who had no choice but to pay what the railroads demanded on these branch lines. The granger movement developed in large part to fight the railroads.

Many states tried to implement laws to control gouging by railroads, but few survived court scrutiny. Railroads were quintessentially "interstate commerce," and only the federal government could regulate them effectively. The result, after much political pushing and shoving - for the railroads had great political influence-was the Interstate Commerce Commission, established in 1887, empowered to ban "personal discrimination," i.e. the railroad practice of giving favored customers lower rates, and to require rates that were "just and reasonable."

The ICC was the first federal regulatory agency and at first was severely limited in its powers by a conservative Supreme Court. But after the court became more liberal in the early 20 th century its powers were expanded. Of course the ICC needed experts in railroading to do its job, and most of those, necessarily, came out of the railroad industry. These experts naturally tended to see things from the railroads' perspective. This is one of the prime reasons regulatory agencies, established to discipline an industry, so often end up in bed with it, a process known as "regulatory capture."

It wasn't long before the ICC evolved into what the railroads had long wanted, an effective cartel that set prices and ensured profits. As early as 1884 a vice president of the Pennsylvania Railroad, one of the country's most powerful, had written that "a large majority of the railroads in the United States would be delighted if a railroad commission or any other power could make rates upon their traffic which would insure [sic] them $6 \%$ dividends, and I have no doubt, with such a guarantee, they would be very glad to come under the direct supervision and operation of the National Government." 8

The earlier cartels had lacked an enforcement mechanism and so always broke down. The ICC proved to be that mechanism. In the 1930's it was given regulatory authority over the nascent trucking industry as well, a move that only

\footnotetext{
${ }^{8}$ Quoted in Friedman, A History of American Law, p. 451.
} 
assured that the railroad's first real competition in the longhaul freight business would not compete with it.

Only in the 1970 's, by which time the railroad industry, thanks to the lack of competition, had become moribund, outdated, and technically backward, did the transportation industry get out from under the ICC cartel and become able to compete on the basis of price once again. It quickly began to evolve into the modern, innovative and profitable industry it is today. The ICC by then had long outlived its usefulness but, because of the immense inertia of politics, it was formally abolished only in 1995.

$* * *$

The incorporation laws that states adopted in the early 19th century often remained unchanged for decades, while the economy in the ever-accelerating Industrial Revolution, changed profoundly and companies grew and achieved national and even global reach. Most dated from before the time the railroads and the telegraph had created an integrated national economy. Many states, including Ohio, did not allow companies to own property out of state or to hold stock in other corporations.

That was an increasing problem for the Standard Oil Company which came to dominate the burgeoning petroleum industry after its development began in the late 1850's. As Standard Oil increased in size by acquiring more and more of its rivals in the oil business, the constrictions of Ohio incorporation law made managing the company effectively more and more difficult. But political opposition made it impossible to change those laws.

At first, as Standard Oil expanded across state lines and purchased numerous subsidiary corporations, an employee would be named as trustee to hold title to the property or stock. This soon became very unwieldy, with dozens of trustees scattered throughout the Standard Oil empire. Henry Flagler, John D. Rockefeller's most important partner, devised a much more efficient way around the outdated law: the trust form of organization. Three men were appointed trustees for all out-of-state holdings. In theory they controlled all Standard Oil property outside of Ohio. In fact, of course, they did exactly as they were told.

The trust form of organization actually lasted only about 10 years. In 1889, New Jersey reformed its incorporation law to bring it up-to-date with the new industrial world. It allowed holding companies and interstate activities. Its reason for doing this was purely self-interested: it wanted the fees that would accrue to the state if companies incorporated there. And, indeed, companies flocked to incorporate in New Jersey, including Standard Oil. Other states then had no real choice but to bring their incorporation laws into rough conformity with those of New Jersey. (This is a great example of the benefits of having 50 semi-sovereign states that can experiment with different approaches to regulation. Good ideas inevitably spread and with fifty state "laboratories," more good ideas will be developed and bad ideas dropped. It's a major American advantage in a globalizing world.

But while the trust form of corporate organization lasted only a decade, the term trust is with us yet, as the word became associated with corporations that increasingly seemed over-powerful and which conspired to prevent competition.

In 1890, the Sherman Antitrust Act passed Congress, one of the first federal laws to regulate the marketplace. It declared that "Every contract, combination in the form of trust or otherwise, or conspiracy, in restraint of trade or commerce among the several States, or with foreign nations, is declared to be illegal."

As with the ICC, the Sherman Act had little effect in the conservative and business-oriented 1890's. But after Theodore Roosevelt became president in September, 1901, with McKinley's assassination, the climate in Washington began to change markedly, and opposition to companies that controlled whole industries became public policy. The formation of U.S. Steel in 1901 by J. P. Morgan, the first company capitalized at more than $\$ 1$ billion, was particularly alarming.

In 1904, the Roosevelt administration announced that it was suing under the Sherman Antitrust Act to prevent the formation of a new Morgan consolidation, the Northern Securities Corporation. Morgan hurried to Washington and said, famously, to the president, "If we have done something wrong, send your man to my man and they can fix it up." It was, in a nutshell, how Morgan viewed the way the world should work, with a business and political elite quietly running the country as fiduciaries for the people.

Roosevelt replied, "that can't be done."

"We don't want to fix it up," the Attorney General Philander Knox told him. "We want to stop it." And they did.

In 1907, the federal government sued Standard Oil to force its break up. In 1911 the Supreme Court, unanimously agreed that it was a combination in restraint of trade and ordered the dismemberment of the largest trust of all. (Ironically, the successor companies fared so well after the break up that the Rockefeller fortune doubled in the next 2 years.)

From this point until the 1970's the federal government would be an active - some would say far too active - referee in the marketplace. Antitrust laws were strengthened in 1914 with the Clayton Antitrust Act, and in the New Deal there was a vast expansion of government regulation and even control of the economy. Some of these were short lived, such as the National Recovery Act of 1933, which established many industrial cartels to prevent "excess competition," an economic theory then much in vogue in the

${ }^{9}$ Quoted in Allen, The Great Pierpont Morgan, p. 220. 
economics profession. Two years later a unanimous Supreme Court threw it out as unconstitutional.

Many other New Deal regulations, however, are with us yet, such as the Federal Deposit Insurance Corporation, established to prevent bank runs, a task at which it has been almost completely successful.

Only in the 1970's did the pendulum begin to swing back the other way with the deregulation of transportation, airlines, and banking and the ban on fixed commissions on Wall Street. Many of these deregulatory reforms were enormously successful. Once railroads, trucks, and airlines, could compete on price, transportation as a percentage of the GDP dropped by a third and air travel increased dramatically. The end of fixed commissions caused the cost of trading securities to drop precipitously and trading-and individual stock ownership — as a result to soar.

$* * *$

As the world adjusts to the enormous potential of the new digital age and the ever-accelerating globalization of the world's economies, new regulatory regimes will be needed to cope with the new problems that will — indeed, already have - arisen. It has become increasingly obvious, for instance, that while the banking and financial sectors are now nearly completely globalized, the regulation of those sectors remain only national in scope. The consequences of this mismatch have been much in the headlines in recent months.

We need to evolve the new regulatory regime needed to ensure the success of the new game of capitalism and the equitable distribution of that success. As we do so in this new "heaving, tumbling age" set off by the microprocessor, it would be well to keep in mind the lessons of the earlier revolution set off by the factory system and the steam engine.

The legal, economic, political, and social systems were all upended by the new technology and the world had to deal with a new world aborning all around it. It did so remarkably well, but the changes were mediated not just by government. Industries and individuals as well played a vital role.

\section{Further Reading}

Alexander, DeAlva Stanwood. 1909. A Political History of New York State.

Allen, Frederick Lewis. 1949. The Great Pierpont Morgan.

Ambrose, Stephen. 2000. Nothing Like It in the World: The Men Who Built the Transcontinental Railroad, 1863-1869.

Bartlett, Irving H. 1978. Daniel Webster.

Brands, H. W. 1995. The Reckless Decade: America in the 1890's.

Carlson, Oliver. 1942. The Man Who Made the News: James Gordon Bennett.

Clews, Henry. 1908. Fifty years in Wall Street.

Commercial and Financial Chronicle

Fowler, William Worthington. 1870. Ten Years in Wall Street.

Fraser's Magazine

Friedman, Lawrence M. 1985. A History of American Law.

Gordon, John Steele. 1999. The Great Game: The Emergence of Wall Street as a World Power, 1653-2000.

Gordon, John Steele. 1988. The Scarlet Woman of Wall Street.

Hadley, Arthur T. 1886. Railroad Transportation-Its History and Its Laws.

Houghton, Walter E. 1957. The Victorian Frame of Mind.

Kennedy, David M. 1999. Freedom from Fear: The American People in Depression and War, 1929-1945.

New York Herald

New York Tribune

Previts, Gary John, and Barbara Dubis Merino, 1969. A History of Accounting in America, 1979

Sobel, Robert. 1999. Panic on Wall Street.

Stedman, Edmund Clarence. 1905. The New York Stock Exchange.

Strouse, Jean. 1999. Morgan: American Financier.

Tanner, Hudson C. 1888. "The Lobby," and Public Men from Thurlow Weed's Time.

John Steele Gordon specializes in business and financial history. He has had articles published in, among others, Forbes, Forbes ASAP, Worth, the New York Times and The Wall Street Journal Op-Ed pages, the Washington Post's Book World and Outlook. He is a contributing editor at American Heritage, where he wrote the "Business of America" column for 18 years. His book, An Empire of Wealth: The Epic History of American Economic Power was published in 2004. This article was written for a conference co-sponsored by the Manhattan Institute and Society. Grateful acknowledgement is given to the Marilyn G. Fedak Capitalism Project for its support. 